IRA-International Journal of Education \& Multidisciplinary Studies

ISSN 2455-2526; Vol.08, Issue 01 (July 2017)

Pg. no. 53-74

Institute of Research Advances

http://research-advances.org/index.php/IJEMS

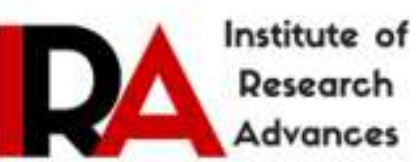

\title{
Influence of Extracurricular Activities on Attachment, Emotion Regulation and Career Aspirations in Adolescents
}

\author{
Nandini Sanyal $^{1 \#}$, Pidathala Saahithi ${ }^{2}$, Tina Fernandes ${ }^{3}$ \\ ${ }^{1}$ Asst. Prof., Dept. of Psychology, St. Francis College for Women, Begumpet, Hyderabad - \\ 500016, India. \\ ${ }^{2}$ Post Graduate Students, St. Francis College for Women, Begumpet, Hyderabad - 500016, India. \\ ${ }^{3}$ Retd Head, Dept. of Psychology, St. Francis College for Women, Begumpet, Hyderabad - \\ 500016, India. \\ \#corresponding author. \\ Type of Review: Peer Reviewed. \\ DOI: http://dx.doi.org/10.21013/jems.v8.n1.p7 \\ How to cite this paper: \\ Sanyal, N., Saahith, P., Fernandes, T. (2017). Influence of Extracurricular Activities on Attachment, \\ Emotion Regulation and Career Aspirations in Adolescents. IRA International Journal of Education and \\ Multidisciplinary Studies (ISSN 2455-2526), 8(1), 53-74. doi: http://dx.doi.org/10.21013/jems.v8.n1.p7
}

(C) Institute of Research Advances.

\section{(cc) EY-NC}

This work is licensed under a Creative Commons Attribution-Non Commercial 4.0 International License subject to proper citation to the publication source of the work.

Disclaimer: The scholarly papers as reviewed and published by the Institute of Research Advances (IRA) are the views and opinions of their respective authors and are not the views or opinions of the IRA. The IRA disclaims of any harm or loss caused due to the published content to any party.

Institute of Research Advances is an institutional publisher member of Publishers Inter Linking Association Inc. (PILA-CrossRef), USA. The institute is an institutional signatory to the Budapest Open Access Initiative, Hungary advocating the open access of scientific and scholarly knowledge. The Institute is a registered content provider under Open Access Initiative Protocol for Metadata Harvesting (OAI-PMH).

The journal is indexed \& included in WorldCat Discovery Service (USA), CrossRef Metadata Search (USA), WorldCat (USA), OCLC (USA), Open J-Gate (India), EZB (Germany) Scilit (Switzerland), Airiti (China), Bielefeld Academic Search Engine (BASE) of Bielefeld University, Germany, PKP Index of Simon Fraser University, Canada. 


\begin{abstract}
The term extracurricular activities are defined as any structured activity supervised by one or more adults outside regular school hours or the home. Attachment is an enduring emotional bond which an individual forms to another person. Emotion regulation refers to how we try to influence which emotions we have, when we have them, and how we experience and express these emotions. Career aspirations are defined as long-term individual work related goals. Non-probability purposive sampling was used to select a sample of 230 adolescents aged 12 to 16 years. They were divided into three groups: not involved, moderately involved and highly involved in extracurricular activities. The study adopts a factorial design to determine whether there are any main and interactional effects of the level of involvement in extracurricular activities and gender on attachment, emotion regulation and career aspirations in adolescents. The study also adopts a correlational design to determine if the dimensions of attachment and emotion regulation predict career aspirations among adolescents who are not involved, moderately involved and highly involved in extracurricular activities The results showed an influence of involvement in extracurricular activities on adolescents' mother attachment, father attachment and peer attachment, and career aspirations. Further, adolescents who are highly involved in extracurricular activities were found to be high on alienation. The predictors for career aspirations and its dimension among adolescents who are not involved and moderately involved were found to be peer attachment and its dimensions. However, for those who are highly involved in extracurricular activities, the predictors for career aspirations were found to be mother and father attachment dimensions. The study recommends encouraging adolescents' participation in extracurricular activities for positive youth development.
\end{abstract}

Keywords: extracurricular activities, attachment, emotion regulation, career aspirations

\title{
INTRODUCTION
}

Research on adolescents has undergone many transitions. Adolescence is seen as a period for identity formation (Erikson, 1959) and social construction (Youniss, 1983) in one's life. In the past few years, adolescents' involvement in extracurricular activities is being seen as a key factor to ensure holistic development. Parents now enroll their children in extracurricular activities not just to ensure admission in reputed educational institutions, but also to keep them engaged in various activities and to provide opportunities for them to choose different careers. Research supports that being involved, over-involved, or not involved at all in extracurricular activities has an impact on what becomes of teens in the future.

The term extracurricular activities is defined as "Any structured activity supervised by one or more adults outside regular school hours or the home. The activity can be sponsored by the school or community and include team sports, pro-social activities such as religious activities or volunteer work, performing arts, school involvement, and academic clubs" (Johnson \& Moulden, 2011). Involvement in extracurricular activities is taken in terms of the number of hours spent in the activity/activities. Extracurricular activities are activities performed by students that fall outside the realm of the normal curriculum of school or university education. Such activities are generally voluntary as opposed to mandatory.

The positive youth development position provides a useful theoretical perspective for studying the benefits associated with extracurricular activities. This theory was developed by the National Conference of State Legislatures (2005). In essence, the positive youth development perspective rests on the idea that children need a well-coordinated array of people, places, and possibilities to help them as they grow and develop (Ferber, Gaines, \& Goodman, 2005). The goal of positive youth development is to develop multi-faceted programs to help children grow into mature and successful adults. Promoting positive relationships with peers, providing opportunities to learn healthy behaviours, connecting youth with caring adults, and challenging youth in ways that build their competence are regarded as key components of high-quality programs.

Students' engagement in extracurricular activities has found wide empirical evidence. Students who participate in extracurricular activities have reduced behaviour problems (Massoni, 2011), higher self-perception (Daley \& Leahy, 2003), social development (Logan \& Scarborough, 2008) and academic achievement (Reeves, 2008). Baker, Akiba, LeTendre (2001) studied that the students active involvement contributes to leadership skills and the ability to plan, manage, organize, implement, and evaluate. The researchers view responsible participation as useful for building character, learning the value of trustworthiness and reliability, and promoting positive public relations throughout schools and communities. 
Of the many contexts in which adolescents develop, family has been given a lot of importance. An important component of adolescents' relationship with parents and peers is attachment. The concept of parent attachment being studied is based on the models and definitions of John Bowlby (1977), Papalia and colleagues (1999) and Ainsworth (1979). Bowlby (1977) defines attachment as an enduring emotional bond which an individual forms to another person. Papalia et al., (1999) define it as a reciprocal, enduring, relationship between infant and caregiver, each of whom contributes to the quality of the relationship. Attachments have adaptive value for babies, ensuring that their psychosocial as well as physical needs will be met. According to Ainsworth (1979), it may be "an essential part of the ground plan of the human species for an infant to become attached to a mother figure".

Another recent conceptualization to attachment was given by Hepper and Carnelley (2012). They found that attachment style influences how an individual interprets feedback from significant others. Individuals with different attachment orientations possess self-concepts differing in valence and structure. These differences are thought to originate in early care giving experiences. But how do they persist into adulthood? One important process by which the self is maintained and developed is receiving self-relevant feedback from others. Feedback provides vital information about strengths and weaknesses, and people often go out of their way to seek it. Seeking particular feedback influences the information one receives in return, contributing to self-concept maintenance and change.

While attachment relationships begin with parents, individuals eventually transition into creating more attachment relationships with peers (Fraley \& Davis, 1997). Attachment relationships between peers seem to include the presence of "enduring affectional bonds" (Ainsworth, 1989). In addition, peer attachment relationships tend to allow for more equal levels of giving and receiving between individuals within the relationship, which is in contrast to infant-adult attachment relationships, where parents generally give more than they receive in the attachment relationship (Hazan \& Zeifman, 1994). Peer attachment relationships also hold value for their ability to provide emotional support (Patterson et al., 1994).

Vast number of studies has linked parent attachment to social skills competence, behaviour, life satisfaction and relationship with peers among adolescents. Engels et al., (2001) found that among 15 to 18 year olds, parental attachment was moderately related to social skills, which, in turn, affected middle adolescents' competence in friendships and romantic relationships. Also, parental attachment and relational competence were significant predictors of adolescents' emotional adjustment in the 12 to 18 age group.

Secure attachment style has been associated with better adjustment, and less likelihood to engage in risky behaviours (Cooper et al., 1998), ability for higher level reasoning in late adolescence (Shea et al., 1991), stability of temperament and social development (Jaffari-Bimmelet al., 2006), greater ability to engage in problem solving discussions, less avoidant, less aggression, \& greater "balanced assertiveness" (Kobak et al., 1993), pro-social behaviour and empathy (Liable et al., 2004).

Studies have also focused on the influence of parent child relationship on the school related behaviours and performance. Results of a study by Murray (2009) indicated that parent-child relationship quality accounted for a significant portion of the variance in student rated school engagement, school competence, and standardized achievement in reading. Another study by Mo and Singh (2008) focused on parents' relationships and involvement in their children's lives and the effects on the students' school engagement and school performance. The results confirmed the importance and significance of parents' involvement in middle school students' school engagement and performance.

During the transition into adolescence, adolescents spend increasing amounts of time alone and with friends, and there is a dramatic drop in time adolescents spend with their parents (Larson \& Richards 1991). Despite these changes in time allocation, research indicates that adolescents' relationships with their parents influence their interactions with peers (Brown et al., 1993). A study by Schneider et al (1996) associated parent attachment with peer relations in adolescents from class $10(\mathrm{n}=63)$. Using the Inventory of Parent Attachment and Interpersonal Competence Questionnaire, the study found that both positive and negative dimensions of parent-adolescent attachment were correlated with adolescent involvement in extracurricular peer activity. Parents who were seen by the adolescents as close and trusting had negative opinions of the adolescents' best friends.

Studies on examining the ways in which peer relationships influence adolescents have provided a number of results. First, peers influence can be negative and positive. Peers influence academic achievement 
and pro-social behaviours (Mounts \& Steinberg 1995, Wentzel \& Caldwell 1997), as well as problem behaviors such as drug and alcohol use, cigarette smoking, and delinquency (Urberg et al., 1997). Second, peers do not influence one another during adolescence through coercive pressures; most adolescents are influenced by peers because they admire them and respect their opinions (Susman et al., 1994). Third, adolescents and their friends are often similar, but not simply because they influence each other (Hartup 1996). Adolescents choose friends with similar behaviours, attitudes, and identities (Akers et al 1998, Hogue \& Steinberg 1995). Finally, susceptibility to peer influence is not uniform among adolescents. Factors such as adolescents' age, personality, socialization history, and perceptions of peers are all important to consider. The studies therefore, highlight the interplay of adolescents' engagement with school and extracurricular activities, their relationships with parents and peers, their self-concept, their leadership skills and their behaviour in general.

Studies have also highlighted how the relationship with caregivers can play a central role in the development of emotion regulation (ER) capacities. For studying emotion regulation, the study adopts the model proposed by Gross (1998). Emotion regulation refers to how we try to influence which emotions we have, when we have them, and how we experience and express these emotions (Gross, 1998). It refers to the process of modulating one or more aspects of an emotional experience or response (Campos \& Sternberg, 1981; Gross, 1998).

Gross (1998) differentiated between two types of regulation strategies on the basis of whether they influence emotions at the input (i.e., antecedent focused; e.g., cognitive reappraisal) or at the output (i.e., response focused; e.g., expressive suppression) phases. Expressive suppression represents a process of consciously inhibiting emotional expression when emotionally aroused (Butler, Wilhelm, \& Gross, 2006; Gross, 1998). At the other end of the emotion generative process is cognitive reappraisal, which involves actively reinterpreting emotive stimuli in terms that modify the emotional impact (Gross, 1998).

Aldao (2013) proposes that the process of emotion regulation can be characterized by the following components: (a) the organism carrying out the regulation; (b) the emotion-eliciting stimuli in the environment; (c) the selection and implementation of strategies; and (d) the types of outcomes considered.

Emotion discrimination, emotion regulation, and cognitive control are three related, yet separable processes that emerge over the course of development. A study by Tottenham, Hare \& Casey (2011) tested 100 children, adolescents, and adults on an Emotional Go/Nogo task, illustrating the ability of this paradigm to identify the unique developmental patterns for each of these three processes in the context of both positive (happy) and negative emotions (fear, sad, and anger), across three different age groups. Findings indicated that emotion discrimination and regulatory abilities (both cognitive control and emotion regulation) improve steadily for each age group, with each age group showing unique patterns of performance. The findings suggest that emotion regulation is constructed from basic cognition control and emotion discrimination skills.

Although adolescents' emotional lives are thought to be more stressful and turbulent than those of adults, it is unknown whether this difference is attributable to developmental changes in emotional reactivity or emotion regulation. Silvers et al., (2012) examined this question in study 1 by presenting healthy individuals aged 10-23 with negative and neutral pictures and asking them to respond naturally or use cognitive reappraisal to down-regulate their responses on a trial-by-trial basis. Study 2 replicated and extended these findings using a different reappraisal task and further showed that situational (i.e., social vs. non-social stimuli) and dispositional (i.e., level of rejection sensitivity) social factors interacted with age to predict regulation success. The results indicated that young adolescents were less successful at regulating responses to social than to non-social stimuli, particularly if the adolescents were high in rejection sensitivity.

Apart from the attachment with parents and peers, school engagement, extracurricular participation, social competence, academic achievement and emotion regulation among adolescents, research has also started to focus on their aspirations towards academics, career and occupation. Career aspirations are defined as longterm individual work related goals (Bos, 2007). For this study, career aspirations have been defined as a concept similar to aspirations in general, educational aspirations, occupational aspirations and vocational aspirations. Although individuals may have different aspirations such as educational and career, aspirations in general have some common features. First, aspirations express goals or goal-orientations (or desired future endstates) that are relevant to well-being, broadly defined. Second, aspirations evolve over time in response to life experience and circumstances (Simon, 1979). Third, as goals, aspirations are an important influence on behaviour (or actions) and thus attainment or outcomes. 
A review of research related to educational and occupational aspirations reveals that important career choices and development processes may occur well before adolescence. In fact, tentative course choices and college plans may be formed in early elementary school (Ring, 1994), with career preferences evident as early as kindergarten (Trice \& King, 1991).

A study by Maher and Abu-Hilal (2000) on high school students $(\mathrm{n}=280)$ found that level of academic aspirations was a mediating factor between attitude towards school subjects and academic achievement. Research has shown middle school students' academic achievement to be directly related to their educational aspirations (Clements \& Kifer, 2001; Garg et al., 2002; Mau \& Bikos, 2000). Mau and Bikos (2000) found academic achievement (based on a reading and math proficiency test) of middle school students to be a predictor of educational aspirations. Further, the researchers found evidence stating that academic achievement was a significant predictor for both educational and career aspirations.

A number of studies have been devoted towards understanding the various environmental factors that affect an adolescent's level of aspirations. A longitudinal study by Wei-Cheng and Bikos (2000) found that sex and race significantly predicted educational and vocational aspirations of students. The researchers also found that compared with other groups, Asian Americans had the greatest increase in educational aspirations. Female students, on the average, had higher educational and vocational aspirations. Silverman and Silverman (1973) reported that in general, 7 th grade girls have higher career aspirations than seventh grade boys.

Another environmental factor found to be influencing aspirations is the parent-adolescent relationship. Research has shown that parental influence on the adolescent's aspirations is much stronger than peer influence (Davies \& Kandel, 1981). In relation to this, Hill and colleagues (2004) conducted a longitudinal study on parent academic involvement, behavioral problems, achievement, and aspirations among 463 adolescents, followed from 7th (approximately 12 years old) through 11th (approximately 16 years old) grades. Parental academic involvement in $7^{\text {th }}$ grade was found to be negatively related to behavioural problems in $8^{\text {th }}$ grade and positively related to students' aspirations in $11^{\text {th }}$ grade. However, there were variations across parental education levels and ethnicity. Further, Whiston and Keller (2004) noted that parental achievement and socioeconomic status as well as parental support and expectations influenced the career aspirations of middle school and high school students.

Chen and colleagues (1980) studied the relationship between locus of control and academic achievement, anxiety, and level of aspiration was examined among 2,438 ninth grade Israel-Jewish students of Asian or African background and European, American, or Israeli backgrounds. Holding the influence of socioeconomic status constant, the researchers found that in general, students having internal locus of control, tend to attain greater academic achievement, to express less anxiety, and to have higher level of aspiration. The relationship between academic achievement, level of aspiration, and the perception of locus of control appears to be accentuated among students of Asian or African origin to a greater extent than among students of European, American, or Israeli origin.

The study aims to observe the effect of level of involvement in extracurricular activities (high involvement, moderate involvement and no involvement) on attachment (mother, father and peer attachment), emotion regulation and career aspirations (leadership, educational and achievement) in high school students. During adolescence, students start to actively engage themselves in activities other than academics. The involvement in extra-curricular activities starts to include competitions and goes beyond being just a hobby. They are more familiar to the activity and are more experienced. Through voluntary participation, the student gives time, energy, and loyalty to the activity. The student accepts the rules, regulations and responsibilities unique to the activity. Given how relationships change during adolescence, questions arise as to if this change is different among students who are highly involved, moderately involved and not involved in extracurricular activities. Taking on from the empirical evidence showing that students involved in extracurricular activities have less behavioural problems, this study aims to find a difference in students' emotion regulation with respect to their level of involvement.

Another important aspect of extracurricular activities is that, the activity sets challenges, benchmarks and goals for the student to achieve on a regular basis. Under professional guidance, the student is actively involved in reaching these goals. Assuming that these activities give an understanding about the student's competence in that activity and their liking towards that activity, the present study aims to see differences in students and their career aspirations, with respect to their level of involvement in extracurricular activities. 


\section{OBJECTIVES}

- To observe the influence of level of involvement in extracurricular activities (high involvement, moderate involvement and no involvement) and gender on attachment (mother, father and peer attachment), emotion regulation and career aspirations (leadership, educational and achievement) in adolescents.

- To observe whether the dimensions of trust, communication and alienation in mother, father and peer attachment predict career aspirations and its dimensions of leadership, educational and achievement aspirations in adolescents who are not involved, moderately involved and highly involved in extracurricular activities.

- To observe whether emotion regulation predicts career aspirations and its dimensions of leadership, educational and achievement aspirations in adolescents who are not involved, moderately involved and highly involved in extracurricular activities.

\section{METHOD}

\section{Research Design}

The study is a quantitative study in which level of involvement in extracurricular activities (high involvement, moderate involvement and no involvement) and gender are treated as the independent variables and attachment (mother, father and peer), emotion regulation and career aspirations (leadership, educational and achievement) are treated as the dependent variables.

The study adopts a factorial design to determine whether there are any main and interaction effects of the level of involvement in extracurricular activities and gender on attachment (mother, father and peer), emotion regulation and career aspirations (leadership, educational and achievement)in adolescents. The study also adopts a correlational design to determine if the dimensions of attachment (mother, father and peer and their dimensions of trust, communication and alienation) and emotion regulation predict career aspirations (leadership, educational and achievement) among adolescents who are not involved, moderately involved and highly involved in extracurricular activities.

\section{Sample}

Non-probability purposive sampling was used to select a sample of 230 adolescents aged 12 to 16 years. An information schedule/screener was used to ascertain the participants' level of involvement in extracurricular activities. The information schedule/screener consisted of questions related to the participants' involvement in extracurricular activities with respect to the number of hours in a day, the number of hours in a week, if under professional guidance, the type of extracurricular activities, etc. Based on the data collected, the sample was divided into two groups: adolescents who are not involved in any extracurricular activities and adolescents who are involved in one or more extracurricular activities. Based on the computed median, the group of adolescents who are involved in extracurricular activities were further divided into 2 groups: Adolescents who are moderately involved in extracurricular activities (1 to 7 hours per week) and adolescents who are highly involved in extracurricular activities ( 8 hours and above per week). The sample division is shown below:

\section{Inclusion Criteria:}

1. Students of $8^{\text {th }}, 9^{\text {th }}$ and $10^{\text {th }}$ classes

2. Students of Indian nationality

\section{Exclusion Criteria:}

1. Physically challenged students.

2. Students below or over the age range 12 to 16 years.

3. Students with history of any chronic physical or psychological disorder were excluded.

4. Students with any family history of chronic physical or psychological disorder were excluded

5. Students studying in boarding schools

6. Students who have failed in any grades

\section{INSTRUMENTS}

Four questionnaires were being used in this study. They are:

\section{Information Schedule:}

Participants were asked to fill in questions regarding their gender, age, class, involvement in extracurricular activities, involvement in leisure activities and the like in writing, on the Information Schedule. 


\section{Inventory of Parent and Peer Attachment Revised (IPPA - R; Greenberg, Seigel, \& Leich, 1984):}

The IPPA was developed in order to assess adolescents' (12 to 19 year olds) perceptions of the positive and negative affective/cognitive dimension of relationships with their parents and close friends, particularly how well these figures serve as sources of psychological security. The theoretical framework is attachment theory, originally formulated by Bowlby (1977) and recently expanded by others. Three broad dimensions are assessed: degree of mutual trust; quality of communication; and extent of anger and alienation.

The revised version (Mother, Father, Peer Version) is comprised of 25 items in each of the mother, father, and peer sections, yielding three attachment scores. Each section measures 3 dimensions of trust, communication and alienation. The instrument is a self-report questionnaire with a five pointlikert-scale response format consisting of "Almost never or never true", "Not very often true", "Sometimes true", "Often true" and "Almost always or always true". The scores are 1 for "Almost never or never true", 2 for "Not very often true", 3 for "Sometimes true", 4 for "Often true" and 5 for "Almost always or always true". Item numbers $3,6,8,9,10,11,14,17,18$ and 23 are reverse scored in mother and father scales. Item numbers 4, 5, 9, 10, 11, 18,22 and 23 are reverse scored in peer scale.

For the revised version, internal reliabilities (Cronbach's alpha) are: Mother attachment: 0.87; Father attachment: 0.89; Peer attachment: 0.92.Parent attachment scores of 12- to 18-year-olds are also moderately correlated with scores on the FACES (Family Adaptability and Cohesion Evaluation Scale), and with the degree of positive family coping (communication among family members and relatives concerning problems) (Lewis, Woods, \& Ellison, 1987). Peer attachment is positively related to social self-concept as assessed by the Tennessee Self Concept Scale and family expressiveness on the Family Environment Scale, and is strongly negatively correlated with loneliness. Peer attachment is modestly correlated with parent attachment as assessed by the IPPA as well as measures of general family functioning and self-concept as family member (Armsden \& Greenberg, 1987; Armsden, 1986; Lewis et al., 1987).The revised version of the IPPA (Mother, Father, Peer version) separately assesses mother and father attachment; the authors recommend its use over the original version whenever possible.

\section{Emotion Regulation Questionnaire for Children and Adolescents (ERQ-CA; MacDermott, Gullone, Allen, King, \& Tonge, 2010):}

The ERQ-CA is a self-report questionnaire assessing the emotion regulation strategies. Higher scores indicate greater use of the emotion regulation strategy. The questionnaire consists of two sub scales measuring the strategies of cognitive reappraisal and expressive suppression. It contains 10 items. Responses are marked on a three point Likert scale( 1 = "Not at all true for me", 2 = "Sort of true for me" and 3 = "Really true for me"). Sample items include "When I want to feel happier about something, I change the way I'm thinking about it" (reappraisal) and "I control my feelings by not showing them" (suppression).

Gullone and Taffe (2011) demonstrated that the ERQ-CA has strong psychometric properties including good internal consistency, and sound construct and convergent validity. For the 4-item Emotion Suppression scale, the alpha coefficient was 0.75 for total sample and for the 6-item Cognitive Reappraisal scale, the alpha coefficient was 0.83 . The scale has been shown to be appropriate for use in non-clinical populations. The measure also demonstrated adequate four-week test-retest reliability $(r=0.54$ for reappraisal, 0.59 for suppression) (MacDermott et al., 2010).

\section{Career Aspiration Scale - Revised (K - CASR; Gregor \& O’Brien, 2015):}

The newly translated K-CASR was used to measure career aspirations. The CASR consists of three subscales including leadership, educational, and achievement aspirations. The leadership aspirations subscale measures the degree to which a person aspires to a leadership position within their career (e.g., "I hope to become a leader in my career field."). The educational aspirations subscale refers to the degree to which a person aspires to continue education or training within knowledge in my field."). Last, the achievement aspirations subscale measures the degree to which a person aspires to significant achievements and recognition within their career (e.g., "I aspire to have my contributions at work recognized by my employer").Participants indicated their degree of agreement with 24 items on a scale from 0 (not at all true of me) to 4 (very true of me).Higher scores indicate higher aspirations in each domain (achievement, leadership, education).

Internal consistency estimates were high on all subscales (achievement $=0.82$, leadership $=0.86$, and educational aspirations $=0.90$ ).In test-retest reliability, data of 29 participants who completed the K-CASR twice (initially and 2 weeks later) was analyzed, to determine whether the measure exhibited stability over time. 
Correlations between the administrations of the measures were as follows: 0.76 for achievement, 0.83 for leadership, and 0.78 for educational aspirations, suggesting that subscale scores were stable over a short period (Gregor \& O'Brien, 2015). In addition, the convergent validity of the K-CASR was supported by relatively strong associations among the subscales and achievement motivation, career orientation, and career goal engagement (Gregor \& O’Brien, 2015).

\section{RESULTS}

Table 1: Showing frequency distribution of the sample $(N=230)$

\begin{tabular}{cccc}
\hline $\begin{array}{c}\text { Group (Involvement } \\
\text { in extracurricular } \\
\text { activities) }\end{array}$ & $\begin{array}{c}\text { Boys } \\
(\mathrm{N}=115)\end{array}$ & $\begin{array}{c}\text { Girls } \\
(\mathrm{N}=115)\end{array}$ & Total \\
\hline f & $\mathrm{f}$ & \\
\hline Not Involved & 41 & 43 & 84 \\
$\begin{array}{c}\text { Moderately Involved } \\
\text { (7 hours and below) }\end{array}$ & 39 & $(51.19)$ & 78 \\
$\begin{array}{c}\text { Highly Involved (8 } \\
\text { hours and above) }\end{array}$ & 35 & 39 & \\
& $(51.47)$ & $(48.53)$ & 68 \\
\hline
\end{tabular}

Table 1 shows that the total sample consists of 230 adolescents. The total number of adolescents who are not involved in any extracurricular activities are 84 . Out of which, $48.81 \%(\mathrm{~N}=41)$ are boys and $51.19 \%(\mathrm{~N}$ $=43$ ) are girls. The total number of adolescents who are moderately involved in extracurricular activities are 78 . Out of which $50 \%$ are boys $(\mathrm{N}=39)$ and $50 \%$ are girls $(\mathrm{N}=39)$. Total number of adolescents who are highly involved in extracurricular activities are 68 . Out of which, $51.47 \%(\mathrm{~N}=35)$ are boys and $48.53 \%(\mathrm{~N}=33)$ are girls.

Table 2: Showing frequency and percentages of hours of involvement (in a week) in extracurricular activities ( $N$ =230)

\begin{tabular}{|c|c|c|c|c|c|c|}
\hline Hours in a week & $\mathrm{f}(\%)$ & Boys & $\mathrm{f}(\%)$ & Girls & $\mathrm{f}(\%)$ & Total \\
\hline 0 & 41 & 35.65 & 43 & 37.39 & 84 & 36.52 \\
\hline 1 & 3 & 2.61 & 1 & 0.86 & 4 & 1.73 \\
\hline 2 & 7 & 6.08 & 4 & 3.47 & 11 & 4.78 \\
\hline 3 & 6 & 5.21 & 4 & 3.47 & 10 & 4.34 \\
\hline 4 & 5 & 4.34 & 1 & 0.86 & 6 & 2.60 \\
\hline 5 & 3 & 2.61 & 6 & 5.21 & 9 & 3.91 \\
\hline 6 & 6 & 5.21 & 9 & 7.82 & 15 & 6.52 \\
\hline 7 & 9 & 7.82 & 14 & 12.17 & 23 & 10 \\
\hline 8 & 3 & 2.61 & 6 & 5.21 & 9 & 3.91 \\
\hline 9 & 1 & 0.86 & 4 & 3.47 & 5 & 2.17 \\
\hline 10 & 2 & 1.73 & 7 & 6.08 & 9 & 3.91 \\
\hline 11 & - & - & 2 & 1.73 & 2 & 1.36 \\
\hline 12 & 6 & 5.21 & 4 & 3.47 & 10 & 6.84 \\
\hline
\end{tabular}




\begin{tabular}{ccccccc}
13 & 3 & 2.61 & 1 & 0.86 & 4 & 1.73 \\
14 & 8 & 6.95 & 3 & 2.61 & 11 & 4.78 \\
15 & 2 & 1.73 & 2 & 1.73 & 4 & 1.73 \\
16 & 3 & 2.61 & 4 & 3.47 & 7 & 3.04 \\
17 & 3 & 2.61 & - & - & 3 & 1.30 \\
18 & 4 & 3.47 & - & - & 4 & 1.73 \\
Total & 115 & 100 & 115 & 100 & 230 & 100 \\
\hline
\end{tabular}

As seen in table 2, the minimum and maximum number of hours indicating the adolescents' involvement in extracurricular activities in a week is 1 hour and 18 hours respectively. Among the adolescents who are moderately involved in extracurricular activities, $1.73 \%, 4.78 \%, 4.34 \%, 2.60 \%, 3.91 \%, 6.52 \%$ and $10 \%$ are involved in 1, 2, 3, 4, 5, 6 and 7 hours per week respectively. Similarly, among the adolescents who are highly involved in extracurricular activities, $3.91 \%, 2.17 \%, 3.91 \%, 1.36 \%, 6.84 \%, 1.73 \%, 4.78 \%, 1.73 \%$, $3.04 \%, 1.30 \%$ and $1.73 \%$ are involved in $8,9,10,11,12,13,14,15,16,17$ and 18 hours per week respectively.

Table 3 showing frequency and percentages of adolescents' involvement in extracurricular activities $(N=146)$.

\begin{tabular}{ccccccc}
\hline Activity & \multicolumn{2}{l}{ Boys $(\mathrm{N}=80)$} & \multicolumn{2}{c}{ Girls $(\mathrm{N}=82)$} & Total & Percentage \\
& $\mathrm{f}$ & $\%$ & $\mathrm{~F}$ & $\%$ & & \\
\hline Dancing & 9 & 11.25 & 27 & 32.92 & 36 & 24.7 \\
Singing & 2 & 2.5 & 23 & 28.04 & 25 & 17.1 \\
Theatre & 3 & 3.75 & 2 & 2.43 & 5 & 3.4 \\
Arts/Crafts & 1 & 1.25 & 28 & 35 & 29 & 19.9 \\
Karate & 4 & 5 & 5 & 6.09 & 9 & 6.2 \\
Badminton & 18 & 22.5 & 20 & 24.39 & 38 & 26 \\
Cricket & 16 & 20 & 5 & 6.09 & 21 & 14.4 \\
Football & 15 & 18.75 & 2 & 2.43 & 17 & 11.6 \\
Basketball & 15 & 18.75 & 24 & 29.26 & 39 & 26.7 \\
Tennis & 18 & 22.5 & 18 & 21.95 & 36 & 24.7 \\
Throw-ball & - & - & 13 & 15.85 & 13 & 8.9 \\
Volleyball & 7 & 8.75 & 2 & 2.43 & 9 & 6.2 \\
Gymnastics & 1 & 1.25 & 74 & 90.24 & 1 & 0.7 \\
Swimming & 13 & 16.25 & 19 & 16.2 & 32 & 21.9 \\
\hline
\end{tabular}

Table 3 shows that maximum number of boys $(\mathrm{N}=80)$ are involved in badminton $(22.5 \%)$ and tennis $(22.5 \%)$, whereas only $1.25 \%$ are involved in arts/crafts and gymnastics. On the other hand, maximum number of girls $(\mathrm{N}=82)$ are involved in gymnastics $(90.24 \%)$ whereas minimum number of girls are involved in volleyball $(2.43 \%)$, football $(2.43 \%)$ and theatre $(2.43 \%)$. 
Table 4 Results of Two-Way ANOVA and descriptive statistics with Attachment (Mother, Father and Peer) and its 3 dimensions: Trust, Communication and Alienation, Emotion Regulation and Aspirations with its 3 dimensions: Leadership, Educational and Achievement Aspirations as dependent variables. Involvement in extracurricular activities (not involved, moderately involved and highly involved) and gender are taken as independent variables $(N=230)$

\begin{tabular}{|c|c|c|c|c|c|c|c|c|}
\hline Variable & $\begin{array}{c}\text { Not } \\
\text { Involved } \\
\text { Mean } \\
\text { (SD) }\end{array}$ & $\begin{array}{l}\text { Moderately } \\
\text { Involved } \\
\text { Mean } \\
\text { (SD) }\end{array}$ & $\begin{array}{l}\text { Highly } \\
\text { Involved } \\
\text { Mean } \\
\text { (SD) }\end{array}$ & $\mathrm{F}$ & $\begin{array}{l}\text { Boys } \\
\text { Mean } \\
(\mathrm{SD})\end{array}$ & $\begin{array}{l}\text { Girls } \\
\text { Mean } \\
(\mathrm{SD})\end{array}$ & $\mathrm{F}$ & $\begin{array}{c}\text { Interaction } \\
\text { Effect } \\
\text { (Gender* } \\
\text { Hours of } \\
\text { Involvement) }\end{array}$ \\
\hline $\begin{array}{l}\text { Attachment } \\
\text { (Mother) }\end{array}$ & $\begin{array}{c}92.5 \\
(16.74)\end{array}$ & $\begin{array}{c}97.45 \\
(13.95)\end{array}$ & $\begin{array}{c}99.72 \\
(13.28)\end{array}$ & $4.67 *$ & $\begin{array}{c}95.38 \\
(14.12)\end{array}$ & $\begin{array}{c}97.21 \\
(15.98)\end{array}$ & 1.14 & 1.12 \\
\hline $\begin{array}{l}\text { Mother } \\
\text { (Trust) }\end{array}$ & $\begin{array}{c}35 \\
(6.56)\end{array}$ & $\begin{array}{l}36.78 \\
(5.35)\end{array}$ & $\begin{array}{l}37.47 \\
(5.32)\end{array}$ & $3.65 *$ & $\begin{array}{l}35.87 \\
(5.44)\end{array}$ & $\begin{array}{l}36.77 \\
(6.26)\end{array}$ & 1.77 & 1.57 \\
\hline $\begin{array}{c}\text { Mother } \\
\text { (Communication) }\end{array}$ & $\begin{array}{c}35 \\
(6.55)\end{array}$ & $\begin{array}{l}36.78 \\
(5.35)\end{array}$ & $\begin{array}{l}37.47 \\
(5.32)\end{array}$ & $3.65 *$ & $\begin{array}{l}35.87 \\
(5.44)\end{array}$ & $\begin{array}{l}36.77 \\
(6.26)\end{array}$ & 1.77 & 1.57 \\
\hline $\begin{array}{c}\text { Mother } \\
\text { (Alienation) }\end{array}$ & $\begin{array}{l}22.5 \\
(4.76)\end{array}$ & $\begin{array}{l}23.88 \\
(4.42)\end{array}$ & $\begin{array}{l}24.78 \\
(3.71)\end{array}$ & $5.25 *$ & $\begin{array}{l}23.63 \\
(4.36)\end{array}$ & $\begin{array}{l}23.65 \\
(4.52)\end{array}$ & 0.01 & 0.65 \\
\hline $\begin{array}{l}\text { Attachment } \\
\text { (Father) }\end{array}$ & $\begin{array}{c}99.76 \\
(13.96)\end{array}$ & $\begin{array}{l}103.41 \\
(13.76)\end{array}$ & $\begin{array}{l}106.72 \\
(15.77)\end{array}$ & $4.29 *$ & $\begin{array}{l}102.44 \\
(14.53)\end{array}$ & $\begin{array}{l}103.64 \\
(14.83)\end{array}$ & 0.51 & 0.84 \\
\hline $\begin{array}{l}\text { Father } \\
\text { (Trust) }\end{array}$ & $\begin{array}{l}42.94 \\
(5.25)\end{array}$ & $\begin{array}{l}43.92 \\
(5.24)\end{array}$ & $\begin{array}{l}44.85 \\
(7.10)\end{array}$ & 1.97 & $\begin{array}{l}43.42 \\
(6.22)\end{array}$ & $\begin{array}{l}44.25 \\
(5.53)\end{array}$ & 1.35 & 0.99 \\
\hline $\begin{array}{c}\text { Father } \\
\text { (Communication) }\end{array}$ & $\begin{array}{l}34.76 \\
(6.39)\end{array}$ & $\begin{array}{l}35.40 \\
(6.90)\end{array}$ & $\begin{array}{l}36.23 \\
(6.64)\end{array}$ & 0.88 & $\begin{array}{l}35.38 \\
(6.64)\end{array}$ & $\begin{array}{l}35.44 \\
(6.67)\end{array}$ & 0.02 & 0.69 \\
\hline $\begin{array}{c}\text { Father } \\
\text { (Alienation) }\end{array}$ & $\begin{array}{l}22.06 \\
(4.29)\end{array}$ & $\begin{array}{l}24.09 \\
(4.18)\end{array}$ & $\begin{array}{l}25.63 \\
(3.94)\end{array}$ & $14.00 *$ & $\begin{array}{l}23.65 \\
(4.27)\end{array}$ & $\begin{array}{l}23.96 \\
(4.51)\end{array}$ & 0.36 & 0.4 \\
\hline $\begin{array}{l}\text { Attachment } \\
\text { (Peer) }\end{array}$ & $\begin{array}{c}93.67 \\
(18.03)\end{array}$ & $\begin{array}{l}101.59 \\
(14.43)\end{array}$ & $\begin{array}{l}101.59 \\
(14.93)\end{array}$ & 7.79 & $\begin{array}{c}92.35 \\
(15.74)\end{array}$ & $\begin{array}{l}104.82 \\
(14.56)\end{array}$ & 40.99 & 0.14 \\
\hline $\begin{array}{l}\text { Peer } \\
\text { (Trust) }\end{array}$ & $\begin{array}{l}39.67 \\
(7.72)\end{array}$ & $\begin{array}{l}43.21 \\
(6.36)\end{array}$ & $\begin{array}{l}43.28 \\
(6.84)\end{array}$ & $7.81 *$ & $\begin{array}{l}39.54 \\
(7.14)\end{array}$ & $\begin{array}{l}44.25 \\
(6.49)\end{array}$ & $29.35^{*}$ & 0.19 \\
\hline $\begin{array}{c}\text { Peer } \\
\text { (Communication) }\end{array}$ & $\begin{array}{l}30.61 \\
(6.93)\end{array}$ & $\begin{array}{l}31.856 \\
(6.78)\end{array}$ & $\begin{array}{l}31.98 \\
(6.15)\end{array}$ & 1.323 & $\begin{array}{l}28.41 \\
(6.00)\end{array}$ & $\begin{array}{l}34.37 \\
(5.92)\end{array}$ & $57.46^{*}$ & 0.13 \\
\hline $\begin{array}{c}\text { Peer } \\
\text { (Alienation) }\end{array}$ & $\begin{array}{l}23.39 \\
(5.87)\end{array}$ & $\begin{array}{l}26.51 \\
(3.98)\end{array}$ & $\begin{array}{l}26.32 \\
(4.44)\end{array}$ & $10.85 *$ & $\begin{array}{l}24.41 \\
(5.47)\end{array}$ & $\begin{array}{l}26.20 \\
(4.50)\end{array}$ & $7.64 *$ & 1.09 \\
\hline
\end{tabular}


Table 4 Continued

\begin{tabular}{|c|c|c|c|c|c|c|c|c|}
\hline Variable & $\begin{array}{c}\text { Not } \\
\text { Involved } \\
\text { Mean } \\
\text { (SD) }\end{array}$ & $\begin{array}{l}\text { Moderately } \\
\text { Involved } \\
\text { Mean } \\
\text { (SD) }\end{array}$ & $\begin{array}{l}\text { Highly } \\
\text { Involved } \\
\text { Mean } \\
\text { (SD) }\end{array}$ & $\mathrm{F}$ & $\begin{array}{l}\text { Boys } \\
\text { Mean } \\
(\mathrm{SD})\end{array}$ & $\begin{array}{l}\text { Girls } \\
\text { Mean } \\
(\mathrm{SD})\end{array}$ & $\mathrm{F}$ & $\begin{array}{c}\text { Interaction } \\
\text { Effect } \\
\text { (Gender* } \\
\text { Hours of } \\
\text { Involvement) }\end{array}$ \\
\hline $\begin{array}{c}\text { Emotion } \\
\text { Regulation }\end{array}$ & $\begin{array}{l}21.18 \\
(3.67)\end{array}$ & $\begin{array}{l}20.67 \\
(3.59)\end{array}$ & $\begin{array}{l}21.43 \\
(2.58)\end{array}$ & 0.99 & $\begin{array}{l}21.16 \\
(3.67)\end{array}$ & $\begin{array}{l}21.00 \\
(3.03)\end{array}$ & 0.16 & 0.19 \\
\hline $\begin{array}{c}\text { Career } \\
\text { Aspirations }\end{array}$ & $\begin{array}{c}70.67 \\
(13.02)\end{array}$ & $\begin{array}{c}75.63 \\
(13.26)\end{array}$ & $\begin{array}{c}75.47 \\
(13.35)\end{array}$ & 3.70* & $\begin{array}{c}72.53 \\
(14.26)\end{array}$ & $\begin{array}{c}74.96 \\
(12.35)\end{array}$ & 1.86 & 0.34 \\
\hline $\begin{array}{l}\text { Leadership } \\
\text { Aspirations }\end{array}$ & $\begin{array}{l}22.20 \\
(5.02)\end{array}$ & $\begin{array}{l}23.56 \\
(5.88)\end{array}$ & $\begin{array}{l}24.48 \\
(6.36)\end{array}$ & 2.99 & $\begin{array}{l}23.22 \\
(6.31)\end{array}$ & $\begin{array}{l}23.49 \\
(5.25)\end{array}$ & 0.06 & 1.15 \\
\hline $\begin{array}{l}\text { Educational } \\
\text { Aspirations }\end{array}$ & $\begin{array}{l}24.08 \\
(5.05)\end{array}$ & $\begin{array}{l}25.83 \\
(5.35)\end{array}$ & $\begin{array}{l}24.79 \\
(5.51)\end{array}$ & 2.30 & $\begin{array}{l}24.27 \\
(5.59)\end{array}$ & $\begin{array}{l}25.48 \\
(4.99)\end{array}$ & 2.98 & 0.53 \\
\hline $\begin{array}{c}\text { Achievement } \\
\text { Aspirations }\end{array}$ & $\begin{array}{l}24.33 \\
(5.72)\end{array}$ & $\begin{array}{l}26.23 \\
(4.74)\end{array}$ & $\begin{array}{l}26.19 \\
(4.73)\end{array}$ & $3.62 *$ & $\begin{array}{l}25.03 \\
(5.45)\end{array}$ & $\begin{array}{l}26.00 \\
(4.86)\end{array}$ & 1.99 & 0.55 \\
\hline
\end{tabular}

Note: ${ }^{*} \mathrm{p}<0.05, \mathrm{df}=229$

Table 5 Showing Post-Hoc Analysis

Involvement in Extracurricular Activities

Not involved and

Moderately involved
Not involved and

Highly Involved
Moderately Involved and Highly Involved

\section{Attachment \\ (Mother) \\ Mother \\ (Trust)}

Mother

(Communication)

Mother

(Alienation)

Attachment

(Father)

Father

(Trust)

Father

(Communication)

Father

(Alienation)

Attachment

(Peer)

Peer
$-4.95$

N.S

N.S

$-1.38$

N.S

N.S

N.S

$-2.03$

N.S

$-3.55$
$-7.22$

$-2.47$

$-2.47$

$-2.28$

N.S

$-6.96$

N.S

N.S

N.S

N.S

N.S

$-3.57$

$-1.54$

N.S

N.S

N.S 
(Trust)

Peer

(Communication)

Peer

(Alienation)

Emotion

Regulation

Career

Aspirations

Leadership Aspirations

Educational Aspirations

Achievement

Aspirations
N.S

$-3.12$

N.S

$-4.96$

N.S

N.S

$-1.90$
N.S

$-2.13$

N.S

$-4.80$

N.S

N.S

$-1.86$
N.S

N.S

N.S

N.S

N.S

N.S

N.S

Table 4 indicates that, there is a significant influence of level of involvement (no involvement, moderate involvement and high involvement) on mother attachment $(F=4.67, p<0.05)$, mother trust $(F=3.65, p<0.05)$, mother communication $(\mathrm{F}=3.65, \mathrm{p}<0.05)$ and mother alienation $(\mathrm{F}=5.25, \mathrm{p}<0.05)$. It is evident from the mean scores that, adolescents who were highly involved in extracurricular activities scored highest with respect to mother attachment $(\mathrm{M}=99.72$, $\mathrm{SD}=13.28)$, followed by adolescents who are moderately involved in extracurricular activities $(\mathrm{M}=97.45, \mathrm{SD}=13.95)$ and adolescents who are not involved in extracurricular activities $(M=92.5, S D=16.74)$. Similarly, adolescents who were highly involved in extracurricular activities scored highest with respect to mother trust $(\mathrm{M}=37.47, \mathrm{SD}=5.32)$, followed by adolescents who are moderately involved in extracurricular activities $(\mathrm{M}=36.78, \mathrm{SD}=5.35)$ and adolescents who are not involved in extracurricular activities $(M=35, \mathrm{SD}=6.55)$. Adolescents who were highly involved in extracurricular activities scored highest also with respect to mother communication $(\mathrm{M}=37.47, \mathrm{SD}=5.32)$, followed by adolescents who are moderately involved in extracurricular activities $(\mathrm{M}=36.78, \mathrm{SD}=5.35)$ and adolescents who are not involved in extracurricular activities $(\mathrm{M}=35, \mathrm{SD}=6.55)$. Adolescents who were highly involved in extracurricular activities scored highest with respect to mother alienation $(\mathrm{M}=24.78, \mathrm{SD}=3.71)$, followed by adolescents who are moderately involved in extracurricular activities $(\mathrm{M}=23.88, \mathrm{SD}=4.42)$ and adolescents who are not involved in extracurricular activities $(\mathrm{M}=22.5, \mathrm{SD}=4.76)$. As is evident from the post hoc analyses results in table 5,adolescents who are highly involved in extracurricular activities scored higher than those who are not involved in extracurricular activities, with respect to mother attachment $(p<0.05)$ and its dimensions of mother trust $(p<0.05)$, mother communication $(p<0.05)$ and mother alienation $(p<0.05)$. Adolescents who are moderately involved in extracurricular activities were seen to have higher scores with respect to mother attachment $(\mathrm{p}<0.05)$ and mother alienation $(\mathrm{p}<0.05)$ than those who were not involved in extracurricular activities. No significant differences were found between adolescents who are moderately involved and not involved in extracurricular activities with respect to mother trust $(\mathrm{p}<0.05)$ and mother communication $(\mathrm{p}<0.05)$. Further, no significant differences were found between adolescents who are highly involved and moderately involved in extracurricular activities with respect to mother attachment $(\mathrm{p}<0.05)$ and its dimensions of mother trust $(\mathrm{p}<0.05)$, mother communication $(\mathrm{p}<0.05)$ and mother alienation $(\mathrm{p}<0.05)$.

Table 4 revealed a significant influence of involvement in extracurricular activities on father attachment $(\mathrm{F}$ $=4.29, \mathrm{p}<0.05)$ and father alienation $(\mathrm{F}=14.00, \mathrm{p}<0.05)$. Father attachment was seen to be highest in adolescents who are highly involved in extracurricular activities $(\mathrm{M}=106.72$, $\mathrm{SD}=15.77)$, followed by adolescents who are moderately involved in extracurricular activities $(\mathrm{M}=103.41, \mathrm{SD}=13.76)$ and adolescents who are not involved in extracurricular activities $(M=99.76, S D=13.96)$. Similarly, father alienation was found to be the highest in adolescents who are highly involved in extracurricular activities $(\mathrm{M}=25.63, \mathrm{SD}=$ $3.94)$, followed by adolescents who are moderately involved in extracurricular activities $(\mathrm{M}=24.09, \mathrm{SD}=4.18)$ and adolescents who are not involved in extracurricular activities $(\mathrm{M}=22.06, \mathrm{SD}=4.29)$. Table 5 indicates that adolescents who are highly involved in extracurricular activities were higher on father attachment $(\mathrm{p}<0.05)$ than those who are not involved in extracurricular activities. Also, adolescents who are highly involved in extracurricular activities were higher on father alienation $(\mathrm{p}<0.05)$ than those who are moderately involved in 
extracurricular activities. Adolescents who are highly involved in extracurricular activities were found to be higher than those who are not involved in extracurricular activities with respect to father alienation $(p<0.05)$. Similarly, father alienation was found to be higher in adolescents who are moderately involved in extracurricular activities than those who are not involved in extracurricular activities $(\mathrm{p}<0.05)$. Further, no significant differences were found between adolescents who are highly involved and moderately involved in extracurricular activities with respect to father attachment $(p<0.05)$. Similarly, no significant differences were found between adolescents who are moderately involved and not involved in extracurricular activities with respect to father attachment $(\mathrm{p}<0.05)$.

Table 4 also indicates that there is a significant influence of level of involvement (no involvement, moderate involvement and high involvement) on peer trust $(F=7.81, p<0.05)$ and peer alienation $(F=10.85$, $\mathrm{p}<0.05)$. Adolescents who are highly involved in extracurricular activities, were seen to have highest peer trust $(\mathrm{M}=43.28, \mathrm{SD}=6.84)$ followed by adolescents who are moderately involved in extracurricular activities $(\mathrm{M}=$ $43.21, \mathrm{SD}=6.36)$ and adolescents who are not involved in extracurricular activities $(\mathrm{M}=39.67, \mathrm{SD}=7.72)$. With respect to peer alienation, adolescents who are moderately involved in extracurricular activities scored highest $(M=26.51, S D=3.98)$ followed by adolescents who are highly involved in extracurricular activities $(M$ $=26.32, \mathrm{SD}=4.44)$ and adolescents who are not involved in extracurricular activities $(\mathrm{M}=23.39, \mathrm{SD}=5.87)$. As is evident from the post hoc analyses results (table5), adolescents who are highly involved in extracurricular activities were seen to have higher peer trust and peer alienation than those who are not involved in extracurricular activities $(\mathrm{p}<0.05)$. Similarly, adolescents who are moderately involved in extracurricular activities were seen to be higher on peer trust and peer alienation as compared to adolescents who are not involved in extracurricular activities $(\mathrm{p}<0.05)$. There were no significant differences between adolescents who are highly involved and moderately involved in extracurricular activities with respect to peer trust $(\mathrm{p}<0.05)$ and peer alienation $(\mathrm{p}<0.05)$.

The results also showed a significant influence of the level of involvement in extracurricular activities on career aspirations $(\mathrm{F}=3.70, \mathrm{p}<0.05)$ and the dimensions of achievement aspiration $(\mathrm{F}=3.62, \mathrm{p}<0.05)$. The results highlighted that with respect to career aspirations, adolescents who are moderately involved in extracurricular activities scored highest $(\mathrm{M}=75.63, \mathrm{SD}=13.26)$, followed by adolescents who are highly involved in extracurricular activities $(\mathrm{M}=75.47, \mathrm{SD}=13.35)$ and adolescents who are not involved in extracurricular activities $(M=70.67, \mathrm{SD}=13.02)$. Similarly, adolescents who are moderately involved in extracurricular activities scored highest in achievement aspirations $(\mathrm{M}=26.23, \mathrm{SD}=4.74)$, followed by adolescents who are highly involved in extracurricular activities $(\mathrm{M}=26.19, \mathrm{SD}=4.73)$ and adolescents who are not involved in extracurricular activities $(\mathrm{M}=24.33, \mathrm{SD}=5.72)$. Further, the post hoc analyses (table 5) shows that with respect to career aspirations and achievement aspirations, adolescents who are highly involved in extracurricular activities scored higher than those adolescents who are not involved in extracurricular activities $(\mathrm{p}<0.05)$. Similarly, adolescents who are moderately involved in extracurricular activities were found to be higher on career aspirations and achievement aspirations than those who are not involved in extracurricular activities $(\mathrm{p}<0.05)$. Also, no significant differences were found between adolescents who are highly involved and moderately involved in extracurricular activities with respect to career aspirations $(\mathrm{p}<0.05)$ and achievement aspirations $(\mathrm{p}<0.05)$.

Furthermore table 4 shows that there is an influence of gender on peer trust $(\mathrm{F}=29.35, \mathrm{p}<0.05)$, peer communication $(\mathrm{F}=57.46, \mathrm{p}<0.05)$ and peer alienation $(\mathrm{F}=7.64, \mathrm{p}<0.05)$. With respect to peer trust, girls $(\mathrm{M}=$ $44.25, \mathrm{SD}=6.49)$ scored higher than boys $(\mathrm{M}=39.54, \mathrm{SD}=7.14)$. Similarly, peer communication was found to be higher in girls $(M=34.37, \mathrm{SD}=5.92)$ than boys $(\mathrm{M}=28.41, \mathrm{SD}=6.00)$ and peer alienation too, was found to be higher in girls $(\mathrm{M}=26.20, \mathrm{SD}=4.50)$ than boys $(\mathrm{M}=24.41, \mathrm{SD}=5.47)$.

It was also observed that there was no influence of level of involvement on father (trust), father (communication), peer (communication), peer attachment, emotion regulation, leadership aspirations and educational aspirations $(\mathrm{p}<0.05)$. Further, there was no influence of gender on mother (trust), mother (communication), mother (alienation), mother attachment, father (trust), father (communication), father (alienation), father attachment, peer attachment, emotion regulation, leadership aspirations, educational aspirations, achievement aspirations and career aspirations $(\mathrm{p}<0.05)$. Further, no interaction effect of level of involvement and gender was found on mother attachment, father attachment and peer attachment and their dimensions of trust, communication and alienation $(\mathrm{p}<0.05)$. No interaction effect was also found with respect to emotion regulation and career aspirations (leadership, educational and achievement aspirations $)(\mathrm{p}<0.05)$. 
Table 6 showing the summary of the step wise regression showing the predictors for career aspirations and its dimensions of leadership, educational and achievement aspirations in adolescents who are not involved in extracurricular activities $(N=84)$.

\begin{tabular}{|c|c|c|c|c|c|}
\hline & Variables & $\begin{array}{c}\text { Career } \\
\text { Aspirations }\end{array}$ & $\begin{array}{l}\text { Leadership } \\
\text { Aspirations }\end{array}$ & $\begin{array}{l}\text { Educational } \\
\text { Aspirations }\end{array}$ & $\begin{array}{l}\text { Achievement } \\
\text { Aspirations }\end{array}$ \\
\hline \multirow{13}{*}{$\beta$} & Mother Attachment & N.S & N.S & N.S & N.S \\
\hline & Mother (Trust) & N.S & N.S & N.S & N.S \\
\hline & Mother(Communication) & N.S & N.S & N.S & N.S \\
\hline & Mother(Alienation) & N.S & N.S & N.S & N.S \\
\hline & Father Attachment & N.S & N.S & N.S & N.S \\
\hline & Father(Trust) & N.S & N.S & N.S & N.S \\
\hline & Father(Communication) & N.S & N.S & N.S & N.S \\
\hline & Father(Alienation) & N.S & N.S & N.S & N.S \\
\hline & Peer Attachment & N.S & N.S & N.S & N.S \\
\hline & Peer(Trust) & N.S & N.S & N.S & N.S \\
\hline & Peer(Communication) & N.S & N.S & $0.27 * *$ & N.S \\
\hline & Peer(Alienation) & N.S & $0.27 * *$ & N.S & N.S \\
\hline & Emotion Regulation & N.S & N.S & N.S & N.S \\
\hline \multirow{14}{*}{$\Delta \mathrm{R}^{2}$} & Mother Attachment & N.S & N.S & N.S & N.S \\
\hline & Mother (Trust) & N.S & N.S & N.S & N.S \\
\hline & Mother(Communication) & N.S & N.S & N.S & N.S \\
\hline & Mother(Alienation) & N.S & N.S & N.S & N.S \\
\hline & Father Attachment & N.S & N.S & N.S & N.S \\
\hline & Father(Trust) & N.S & N.S & N.S & N.S \\
\hline & Father(Communication) & N.S & N.S & N.S & N.S \\
\hline & Father(Alienation) & N.S & N.S & N.S & N.S \\
\hline & Peer Attachment & N.S & N.S & N.S & N.S \\
\hline & Peer(Trust) & N.S & N.S & N.S & N.S \\
\hline & Peer(Communication) & N.S & N.S & 0.07 & N.S \\
\hline & Peer(Alienation) & N.S & 0.07 & N.S & N.S \\
\hline & Emotion Regulation & N.S & N.S & N.S & N.S \\
\hline & Total Adjusted R² & & 0.06 & 0.06 & \\
\hline
\end{tabular}

Detailed regression analysis for each criterion variable in each group is presented in Table 7.

Table 7 Showing Stepwise Regression Analysis among adolescents who are not involved in extracurricular activities $(N=84)$

\begin{tabular}{ccc}
\hline Predictor & $\Delta \mathrm{R}^{2}$ & $\mathrm{~B}$ \\
\hline $\begin{array}{c}\text { Model 1 } \\
\text { Peer } \\
\text { (Alienation) }\end{array}$ & \multicolumn{2}{c}{ Criterion Variable: Leadership Aspirations } \\
Total Adjusted $\mathrm{R}^{2}$ & 0.07 & $0.27 *$ \\
& 0.06
\end{tabular}

Criterions Variable: Educational Aspirations 
Peer

$0.27 * *$

(Communication)

Total Adjusted R ${ }^{2}$

0.06

$*^{*} \mathrm{p}<0.01,{ }^{*} \mathrm{p}<0.05, * * * \mathrm{p}<0.001, \mathrm{~N}=82, \beta=$ Standardized Beta Coefficient, $\mathrm{R}=$ co-efficient of correlation, $\Delta$ $\mathrm{R} 2$ = change in $\mathrm{R}$ squared

Table 7 shows that the contribution of peer alienation in predicting leadership aspirations is $7 \%$. The contribution of peer communication in predicting educational aspirations has also been found to be $7 \%$. The positive $\beta$ value of peer alienation showed a positive correlation with leadership aspirations $(\beta=0.27)$. Similarly, the positive $\beta$ value of peer (communication) showed a positive correlation with educational aspirations $(\beta=0.27)$.

Table 8 showing the summary of the step wise regression showing the predictors for career aspirations and its dimensions of leadership, educational and achievement aspirations in adolescents who are moderately involved in extracurricular activities $(N=78)$.

\begin{tabular}{|c|c|c|c|c|c|}
\hline & Variables & $\begin{array}{c}\text { Career } \\
\text { Aspirations }\end{array}$ & $\begin{array}{l}\text { Leadership } \\
\text { Aspirations }\end{array}$ & $\begin{array}{l}\text { Educational } \\
\text { Aspirations }\end{array}$ & $\begin{array}{l}\text { Achievement } \\
\text { Aspirations }\end{array}$ \\
\hline \multirow{13}{*}{$\beta$} & Mother Attachment & N.S & N.S & N.S & N.S \\
\hline & Mother (Trust) & N.S & N.S & N.S & N.S \\
\hline & Mother(Communication) & N.S & N.S & N.S & N.S \\
\hline & Mother(Alienation) & N.S & N.S & N.S & N.S \\
\hline & Father Attachment & N.S & N.S & N.S & N.S \\
\hline & Father(Trust) & N.S & N.S & N.S & N.S \\
\hline & Father(Communication) & N.S & N.S & N.S & N.S \\
\hline & Father(Alienation) & N.S & N.S & N.S & N.S \\
\hline & Peer Attachment & N.S & N.S & N.S & $0.42 * * *$ \\
\hline & Peer(Trust) & N.S & N.S & $0.44 * * *$ & N.S \\
\hline & Peer(Communication) & $0.46 * * *$ & $0.36 * * *$ & N.S & N.S \\
\hline & Peer(Alienation) & N.S & N.S & N.S & N.S \\
\hline & Emotion Regulation & N.S & $0.17 * *$ & N.S & N.S \\
\hline \multirow{14}{*}{$\Delta \mathrm{R}^{2}$} & Mother Attachment & N.S & N.S & N.S & N.S \\
\hline & Mother (Trust) & N.S & N.S & N.S & N.S \\
\hline & Mother(Communication) & N.S & N.S & N.S & N.S \\
\hline & Mother(Alienation) & N.S & N.S & N.S & N.S \\
\hline & Father Attachment & N.S & N.S & N.S & N.S \\
\hline & Father(Trust) & N.S & N.S & N.S & N.S \\
\hline & Father(Communication) & N.S & N.S & N.S & N.S \\
\hline & Father(Alienation) & N.S & N.S & N.S & N.S \\
\hline & Peer Attachment & N.S & N.S & N.S & 0.17 \\
\hline & Peer(Trust) & N.S & N.S & 0.19 & N.S \\
\hline & Peer(Communication) & 0.21 & 0.13 & N.S & N.S \\
\hline & Peer(Alienation) & N.S & N.S & N.S & N.S \\
\hline & Emotion Regulation & N.S & 0.06 & N.S & N.S \\
\hline & Total Adjusted $\mathrm{R}^{2}$ & 0.20 & 0.17 & 0.18 & 0.17 \\
\hline
\end{tabular}

$* * \mathrm{p}<0.01,{ }^{*} \mathrm{p}<0.05,{ }^{*} * \mathrm{p}<0.001, \mathrm{~N}=82, \beta=$ Standardized Beta Coefficient, $\Delta \mathrm{R} 2=$ change in $\mathrm{R}$ squared

Detailed regression analysis for each criterion variable in each group is presented in Table 9. 
Table 9 Showing Stepwise Regression Analysis among adolescents who are moderately involved in extracurricular activities $(N=78)$

\begin{tabular}{ccc}
\hline Predictor & $\Delta \mathrm{R}^{2}$ & $\mathrm{~B}$ \\
\hline $\begin{array}{c}\text { Model 1 } \\
\text { Peer }\end{array}$ & Criterions Variable: Career Aspirations \\
(Communication) & 0.21 & $0.46^{* * *}$ \\
Total Adjusted $\mathrm{R}^{2}$ & & \\
To & 0.20
\end{tabular}

Criterion Variable: Leadership Aspirations

Model 1

Peer (Communication)

Model 2

Peer

(Communication)

Emotion Regulation

Total Adjusted R ${ }^{2}$

Model 1

Peer

(Trust)

Total Adjusted R ${ }^{2}$

Model 1

Attachment

(Peer)

Total Adjusted R ${ }^{2}$
0.13

$0.36 * * *$

0.06

$0.17 * *$

0.17

$\underline{\text { Criterion Variable: Educational Aspirations }}$

0.19

$0.44 * * *$

0.18

Criterion Variable: Achievement Aspirations

0.17

$0.42 * * *$

$* * \overline{\mathrm{p}}<0.01,{ }^{*} \mathrm{p}<0.05, * * * \mathrm{p}<0.001, \mathrm{~N}=78, \beta=$ Standardized Beta Coefficient, $\mathrm{R}=$ co-efficient of correlation, $\Delta \mathrm{R} 2$ $=$ change in $\mathrm{R}$ squared

Table 9 indicates that in adolescents who are moderately involved, the contribution of peer communication in predicting career aspirations was found to be $21 \%$. The positive $\beta$ value $(0.46)$ represents a positive correlation between career aspirations and peer communication. In predicting achievement aspirations, the contribution of attachment with peers was found to be $17 \%$. The positive $\beta$ value $(0.42)$ shows that there is positive correlation between achievement aspirations and peer attachment.

The table also shows that contribution of peer communication in predicting leadership aspirations is $13 \%$. Emotion Regulation was found to be another predictor of leadership aspirations and the contribution was found to be $6 \%$. The positive $\beta$ value represent a positive correlation between leadership aspirations and peer communication $(\beta=0.36)$. The positive $\beta$ value also represent a positive correlation between leadership aspirations and emotion regulation $(\beta=0.17)$. Peer communication and emotion regulation together contribute $17 \%$ of the overall variance in leadership aspirations among adolescents who are moderately involved in extracurricular activities.

Peer trust was found to be a significant predictor of educational aspirations. The contribution of peer trust in predicting educational aspirations was found to be $19 \%$. The positive $\beta$ value show that peer trust is positively correlated with educational aspirations $(\beta=0.44)$. 
Further, peer attachment was found to be a significant predictor in achievement aspirations. The contribution of peer attachment in predicting achievement aspirations was found to be $17 \%$. The positive $\beta$ value $(\beta=0.42)$ represents a positive correlation between peer attachment and achievement aspirations.

Table 10 showing the summary of the step wise regression showing the predictors for career aspirations and its dimensions of leadership, educational and achievement aspirations in adolescents who are highly involved in extracurricular activities $(N=68)$.

\begin{tabular}{|c|c|c|c|c|c|}
\hline & Variables & $\begin{array}{c}\text { Career } \\
\text { Aspirations }\end{array}$ & $\begin{array}{l}\text { Leadership } \\
\text { Aspirations }\end{array}$ & $\begin{array}{l}\text { Educational } \\
\text { Aspirations }\end{array}$ & $\begin{array}{l}\text { Achievement } \\
\text { Aspirations }\end{array}$ \\
\hline \multirow{13}{*}{$\beta$} & Mother Attachment & N.S & N.S & N.S & N.S \\
\hline & Mother (Trust) & $0.45 * * *$ & N.S & N.S & N.S \\
\hline & Mother(Communication) & N.S & N.S & $0.54 * * *$ & N.S \\
\hline & Mother(Alienation) & N.S & N.S & N.S & N.S \\
\hline & Father Attachment & $0.36 * *$ & $0.43 *$ & N.S & N.S \\
\hline & Father(Trust) & N.S & N.S & N.S & N.S \\
\hline & Father(Communication) & N.S & N.S & N.S & N.S \\
\hline & Father(Alienation) & N.S & N.S & N.S & N.S \\
\hline & Peer Attachment & N.S & N.S & N.S & N.S \\
\hline & Peer(Trust) & N.S & N.S & N.S & $0.34 * *$ \\
\hline & Peer(Communication) & N.S & N.S & N.S & N.S \\
\hline & Peer(Alienation) & N.S & N.S & N.S & $-0.39 * *$ \\
\hline & Emotion Regulation & $0.25 * *$ & N.S & $0.30 * *$ & N.S \\
\hline \multirow{14}{*}{$\Delta \mathrm{R}^{2}$} & Mother Attachment & N.S & N.S & N.S & N.S \\
\hline & Mother (Trust) & 0.21 & N.S & N.S & N.S \\
\hline & Mother(Communication) & N.S & N.S & 0.29 & N.S \\
\hline & Mother(Alienation) & N.S & N.S & N.S & N.S \\
\hline & Father Attachment & 0.04 & 0.18 & N.S & N.S \\
\hline & Father(Trust) & N.S & N.S & N.S & N.S \\
\hline & Father(Communication) & N.S & N.S & N.S & N.S \\
\hline & Father(Alienation) & N.S & N.S & N.S & N.S \\
\hline & Peer Attachment & N.S & N.S & N.S & N.S \\
\hline & Peer(Trust) & N.S & N.S & N.S & 0.12 \\
\hline & Peer(Communication) & N.S & N.S & N.S & N.S \\
\hline & Peer(Alienation) & N.S & N.S & N.S & 0.11 \\
\hline & Emotion Regulation & 0.06 & N.S & 0.08 & N.S \\
\hline & Total Adjusted R² & 0.28 & 0.17 & 0.36 & 0.20 \\
\hline
\end{tabular}

${ }^{* *} \mathrm{p}<0.01,{ }^{*} \mathrm{p}<0.05,{ }^{* * *} \mathrm{p}<0.001, \mathrm{~N}=82, \beta=$ Standardized Beta Coefficient, $\Delta \mathrm{R} 2=$ change in $\mathrm{R}$ squared

Detailed regression analysis for each criterion variable in each group is presented in Table 11.

Table 11 Showing Stepwise Regression Analysis among adolescents who are highly involved in extracurricular activities $(N=68)$

\begin{tabular}{|c|c|c|}
\hline Predictor & $\Delta \mathrm{R}^{2}$ & $\beta$ \\
\hline $\begin{array}{l}\text { Model } 1 \\
\text { Mother } \\
\text { (Trust) }\end{array}$ & $\frac{\mathrm{le}: \mathrm{Ca}}{0.21}$ & $0.45 * * *$ \\
\hline $\begin{array}{c}\text { Model } 2 \\
\text { Mother } \\
\text { (Trust) }\end{array}$ & 0.06 & $0.26 * *$ \\
\hline $\begin{array}{l}\text { Model } 3 \\
\text { Mother }\end{array}$ & 0.04 & $0.25^{*}$ \\
\hline
\end{tabular}


(Trust)

Emotion Regulation

Attachment

(Father)

Total Adjusted R ${ }^{2}$

Model 1

Attachment

(Father)

Total Adjusted R ${ }^{2}$

Model 1

Mother

(Communication)

Model 2

Mother

(Communication)

Emotion Regulation

Total Adjusted R ${ }^{2}$

Model 1

Peer

(Trust)

Model 2

Peer

(Trust)

Peer

(Alienation)
0.43

Criterion Variable: Leadership Aspirations

0.17

$\underline{\text { Criterion Variable: Educational Aspirations }}$

0.54

0.61

0.08

0.29

$0.35 * * *$

$0.36 * *$

0.28

0.18

29

0.

$0.54 * * *$

$0.30 * *$

0.36

$\underline{\text { Criterion Variable: Achievement Aspirations }}$

0.34

0.12

0.11

0.48

$-0.39 * *$

Total Adjusted R ${ }^{2}$

0.20

$* * \mathrm{p}<0.01, * \mathrm{p}<0.05, * * * \mathrm{p}<0.001, \mathrm{~N}=68, \beta=$ Standardized Beta Coefficient, $\mathrm{R}=$ co-efficient of correlation, $\Delta$ $\mathrm{R} 2$ = change in $\mathrm{R}$ squared

As is evident from the above tables, among adolescents who are highly involved, the predictors for career aspirations were found to be mother trust, emotion regulation and father attachment with contributions of $21 \%$, $6 \%$ and $4 \%$ respectively. The positive $\beta$ values represent a positive relationship between career aspirations and mother trust $(\beta=0.45)$, emotion regulation $(\beta=0.26)$ and father attachment $(\beta=0.36)$. Mother trust, emotion regulation and father attachment together contribute $28 \%$ of the overall variance in career aspirations among adolescents who are highly involved in extracurricular activities.

The contribution of father attachment to leadership aspirations is $18 \%$. The positive $\beta$ value $(0.43)$ represents a positive correlation between leadership aspirations and father attachment.

Mother communication was found to be a predictor of educational aspirations. The contribution of mother communication to educational aspirations was found to be $29 \%$. Another predictor of educational aspirations was emotion regulation. The contribution was found to be $8 \%$. Mother communication and emotion regulation together contribute $36 \%$ of the overall variance in educational aspirations among adolescents who are highly involved in extracurricular activities. The positive $\beta$ value $(0.30)$ shows that mother communication is positively 
correlated with educational aspirations. Emotional regulation $(\beta=0.30)$ was also found to be positively correlated with educational aspirations.

In predicting achievement aspirations, the contribution of peer (trust) was found to be $12 \%$ and the contribution of peer alienation was $11 \%$. Peer trust and peer alienation together contribute $20 \%$ of the overall variance in achievement aspirations among adolescents who are highly involved in extracurricular activities. The positive $\beta$ value ( 0.34 ) shows that there is positive correlation between achievement aspirations and peer trust. The negative $\beta$ value (-0.39) represented a negative correlation between achievement aspirations and peer alienation.

\section{DISCUSSION}

Extensive amount of research has been devoted to the benefits of adolescents' involvement in extracurricular activities. The present study has found that adolescents who are involved in extracurricular activities (moderately and highly involved) are higher on mother attachment, father attachment and trust in peers than those who are not involved in extracurricular activities. Extracurricular activities are often considered to be ideal contexts to facilitate the physical, behavioural, intellectual, social, and emotional development of youth (Bloomfield \& Barber, 2009). As Fullarton (2002) says, a "less formal setting than the classroom" may provide opportunities for youngsters to develop "personal and social" skills in developing positive relationships.

The study by Gardner, Roth, and Brooks-Gunn (2008) indicated that it is important to look at the intensity and level of involvement the student has with the activity. Level of participation may make a difference in how much a student is affected by being involved.

For example, consistent with the present study, longer periods of participation have been found to facilitate the kind of positive interpersonal relationships that are thought to encourage positive youth development (Wilson, 2009). Morrissey (2005) describes positive youth development as encompassing five constructs: (1) competence in academic, social, and vocational areas; (2) confidence; (3) character (4) caring and compassion and (5) connection to family, community, and peers.

However, the present study also found that with increase in the involvement in extracurricular activities, adolescents experienced more alienation in their relationships with mother, father and peer. This could be a consequence of two main factors. First, the adolescent period is seen as one conducive to alienation (Calabrese, 1987).Two, social scientists have suggested that alienation emanates from the adolescent's environment and is exacerbated by bureaucratic social organizations that disfranchise the adolescent (Bronfenbrenner, 1986).Thus, alienation could be a result of hectic and restricted lifestyles, reduced quality time and interaction with parents and peers, lack of autonomy, increased involvement in leisure activities such as social media, stress related to academics and the extracurricular activity. Extracurricular activities require the adolescent to be detached or alienated from his home environment. This also could be an explanation for the alienation being experienced by adolescents who are involved in extracurricular activities.

Therefore, the present study is partly consistent with the overscheduling hypothesis. There is a growing concern that some youth are overscheduled in extracurricular activities, and that this increasing involvement has negative consequences for youth functioning (Fredricks, 2012). The over-scheduling hypothesis (Mahoney, Harris, \& Eccles, 2006) posits that youth who participate in too many extracurricular activities could experience poor adjustment and stress, spend less time with family, and experience an early movement into adult roles (Rosenfeld \& Wise, 2000).

Children today may be spending a large fraction of time in highly structured activities, such as sports programs, church-sponsored activities, and other school-sponsored programs which leave them with little time for spending quality time with their family and doing relaxing activities such as reading (Hofferth \& Sandberg, 2001). Pressure from parents to participate along with the activity-related time commitments are believed to contribute to poor psychosocial adjustment for youth and undermine family functioning. Further, research indicated that the dimensions of family function such as affection involvement, roles, communication, and emotional responses positively predict adolescent alienation (Fuzhen \& Wenxin, 2008).

Further, the present study has found that achievement aspirations and career aspirations were the highest among adolescents who are moderately involved in extracurricular activities, followed by those who are highly involved and those who are not involved in extracurricular activities. Consistent with this, a study by Newton (1992) discovered that the level of activity involvement (amount of hours spent) had significant relational impact on behaviour for students; outcome data was best for moderately involved students as compared to both 
high and low level participants (Newton, 1992). In various activity contexts, adolescents likely form judgments about certain tasks commonly valued within that cultural context. For example, youth who participate in service oriented activities or team sports may come to value tasks associated with working with and helping others. Youth involved in activities that emphasize individual contributions may come to value tasks that provide autonomy and freedom to make decisions (Askew, 2013). Further, Massoni (2011) posits that "by participating in extracurricular activities students learn lessons in leadership, teamwork, organization, analytical thinking, problem solving, time management, learning to juggle many tasks at once and it allows them to discover their talents. When a student decides they want to join an extracurricular activity, they look for one that interests them and one that they like or enjoy. When students are in high school or college, this could be the thing that helps them find a career. By participating in extracurricular activities, they will find something they enjoy and see how they can use that as a career. These students will then have higher career aspirations."

The reduction in aspirations among adolescents who are highly involved in extracurricular activities however, could be a result of stress and anxiety caused due to overscheduling in extracurricular activities (Melman, Shari, Little \& Little, 2007) and the alienation felt in their relationships. Aspirations is seen as one that is shaped by intrapersonal and extra-personal environments (Haller, 1968).

Participation in extracurricular activities is seen as a facilitator of personal growth in adolescents. Dworkin, Larson and Hansen (2003) conducted a study comprising of 10 focus groups aimed at getting high school students' descriptions of their "growth experiences" in these activities. The youth reported both personal and interpersonal processes of development. The personal experiences included experimentation and identity work, development of initiative skills such as learning to set goals and manage time, and learning strategies for emotional regulation. However, contrary to this, the present study has found no influence of extracurricular activities on adolescents' emotion regulation.

The present study has found no influence of extracurricular activities on emotion regulation of adolescents. However, research states that emotion regulation emerges through reciprocal interaction with one's social environment (Saarni, 1999). The professional guidance received through extracurricular activities plays a major role in modeling emotion regulation. Following increasingly sophisticated display rules, as well as acquiring emotion-regulation skills, helps children and adolescents to develop an understanding that the emotions expressed do not necessarily correspond to emotions experienced (Zeman et al., 2006).The learning experience of adolescents in an extracurricular activity (learning to regulate emotions) thus, can be associated with the adult supervision that is being offered and the various features and characteristics of such activity.

The present study has found that among adolescents who are not involved and moderately involved in extracurricular activities, career aspirations and its dimensions were largely predicted by dimensions of peer attachment. However, in adolescents who are highly involved in extracurricular activities, the major predictors of career, leadership and educational aspirations were the dimensions of mother and father attachment. Thus, the level of competition, demands relating to commitment, parental trust and communication and parental expectations could be playing a role in the adolescents' career aspirations. The influence of significant others on career aspirations in adolescents has long been established (Sewell, Haller \& Ohlendorf, 1970). Research has offered mixed evidence in predicting which significant others have more influence on adolescents' aspirations. While some researchers have found higher influence of peers on adolescents' aspirations (Alexander \& Campbell, 1964), others have emphasized on parental influence (Davies \& Kandel, 1981).

The current study has certain limitations. The type of extracurricular activities that adolescents are involved in have not been considered. School based activities have also been eliminated.

\section{Recommendations:}

The present study highlights the positive aspects of extracurricular activities. The study encourages adolescents' participation and regular involvement in extracurricular activities to foster positive youth development. However, given the negative consequences such as feeling alienated and having lower academic and career aspirations, the present study recommends to avoid overscheduling of adolescents in extracurricular activities. The effects of longer hours of involvement in extracurricular activities should be weighed and analysed.

Adolescents may benefit from extracurricular activities that not only involve physical exercise or tasks but also skill training and mentoring in stress reduction and emotion regulation. The activities may also consist of increased adolescent-parent interactions and parental involvement. Extracurricular activities may be focused on supporting and motivating adolescents towards their aspirations. 


\section{REFERENCES}

1. Ainsworth, M. S. (1979). Infant-mother attachment. American psychologist, 34(10), 932.

2. Aldao, A. (2013). The future of emotion regulation research capturing context. Perspectives on Psychological Science, 8(2), 155-172.

3. Alexander Jr, C. N., \& Campbell, E. Q. (1964). Peer influences on adolescent educational aspirations and attainments. American Sociological Review, 568-575.

4. Baker, D. P., Akiba, M., LeTendre, G. K., \& Wiseman, A. W. (2001). Worldwide shadow education: Outside-school learning, institutional quality of schooling, and cross-national mathematics achievement. Educational Evaluation and Policy Analysis, 23(1), 1-17.

5. BAR- TAL, D., Kfir, D., Bar Zohar, Y., \& Chen, M. (1980).The relationship between locus of control and academic achievement, anxiety, and level of aspiration. British Journal of Educational Psychology, 50(1), 53-60.

6. Bowlby, J. (1977). The making and breaking of affectional bonds. II. Some principles of psychotherapy. The fiftieth Maudsley Lecture. The British Journal of Psychiatry, 130(5), 421-431.

7. Campos, J. J., Sternberg, C., Lamb, M., \& Sherrod, L. (1981). Infant social cognition: Empirical and theoretical considerations.

8. Cooper, M. L., Shaver, P. R., \& Collins, N. L. (1998). Attachment styles, emotion regulation, and adjustment in adolescence. Journal of personality and social psychology, 74(5), 1380.

9. Davies, M., \& Kandel, D. B. (1981). Parental and peer influences on adolescents' educational plans: Some further evidence. American journal of Sociology, 363-387.

10. Engels, R. C., Finkenauer, C., Meeus, W., \&Deković, M. (2001). Parental attachment and adolescents' emotional adjustment: The associations with social skills and relational competence. Journal of Counseling Psychology, 48(4), 428.

11. Erikson, E. H. (1959). Identity and the life cycle: Selected papers. Psychological issues.

12. Erin E. Brannon (2009), "The Development of Emotion Regulation in Children: The Role of Temperament and Parent Socialization".

13. Ferber, T., Gaines, E., \& Goodman, C. (2005, October).Strengthening Youth Policy. Positive Youth Development: State Strategies. Research and Policy Report. In Forum for Youth Investment.Forum for Youth Investment. The Cady-Lee House, 7064 Eastern Avenue NW, Washington, DC 20012-2031.

14. Fraley, R. C., \& Davis, K. E. (1997). Attachment formation and transfer in young adults' close friendships and romantic relationships. Personal relationships, 4(2), 131-144.

15. Garg, R., Kauppi, C., Lewko, J., \& Urajnik, D. (2002).A structural model of educational aspirations. Journal of Career Development, 29(2), 87-108.

16. Hazan, C., \& Zeifman, D. (1999).Pair bonds as attachments. Handbook of attachment: Theory, research, and clinical applications, 336-354.

17. Hepper, E. G., \& Carnelley, K. B. (2010).Adult attachment and feedback-seeking patterns in relationships and work. European Journal of Social Psychology, 40, 448- 464.

18. Hill, N. E., Castellino, D. R., Lansford, J. E., Nowlin, P., Dodge, K. A., Bates, J. E., \& Pettit, G. S. (2004). Parent academic involvement as related to school behavior, achievement, and aspirations: Demographic variations across adolescence. Child development, 75(5), 1491-1509.

19. Holloway, J. H. (2002). Extracurricular Activities and Student Motivation. Educational Leadership, 60(1), 80-81.

20. Jaffari-Bimmel, N., Juffer, F., Van Ijzendoorn, M. H., Bakermans-Kranenburg, M. J., \& Mooijaart, A. (2006). Social development from infancy to adolescence: Longitudinal and concurrent factors in an adoption sample. Developmental Psychology, 42(6), 1143.

21. Johnson, R., \& Moulden, R. (2011).A Correlational Study of Extracurricular Involvement and Homework Performance of Third Grade Students. Online Submission.

22. Kobak, R. R., Cole, H. E., Ferenz-Gillies, R., Fleming, W. S., \& Gamble, W. (1993). Attachment and emotion regulation during mother-teen problem solving: A control theory analysis. Child development, 231-245.

23. Laible, D. J., Carlo, G., \& Roesch, S. C. (2004). Pathways to self-esteem in late adolescence: The role of parent and peer attachment, empathy, and social behaviours. Journal of adolescence, 27(6), 703-716.

24. Logan, W., \& Scarborough, J. (2008). Connections through clubs: Collaboration and coordination of a schoolwide program. Professional School Counseling, 12(2), 157-161.

25. Massoni, E. (2011). Positive effects of extracurricular activities on students. ESSAI, 9(1), 27.

26. Mo, Y., \& Singh, K. (2008). Parents' relationships and involvement: Effects on students' school engagement and performance. RMLE Online, 31(10), 1-11.

27. Mounts, N. S., \& Steinberg, L. (1995).An ecological analysis of peer influence on adolescent grade point average and drug use. Developmental Psychology, 31(6), 915. 
28. Murray, C. (2009). Parent and teacher relationships as predictors of school engagement and functioning among low-income urban youth. The Journal of Early Adolescence.

29. Papalia, D. E., Gross, D. L., \& Feldman, R. D. (2003). Child development: A topical approach. McGraw-Hill Humanities, Social Sciences \& World Languages.

30. Paterson, J. E., Field, J., \& Pryor, J. (1994).Adolescents' perceptions of their attachment relationships with their mothers, fathers, and friends. Journal of youth and adolescence, 23(5), 579-600.

31. Schneider, B. H., \& Younger, A. J. (1996). Adolescent-Parent Attachment and Adolescents' Relations with their Peers A Closer Look. Youth \& Society, 28(1), 95-108.

32. Silvers, J. A., McRae, K., Gabrieli, J. D., Gross, J. J., Remy, K. A., \& Ochsner, K. N. (2012). Agerelated differences in emotional reactivity, regulation, and rejection sensitivity in adolescence. Emotion, 12(6), 1235.

33. Simon, H. A. (1979). Models of thought (Vol. 1). Yale University Press.

34. Tottenham, N., Hare, T. A., \& Casey, B. J. (2011).Behavioral assessment of emotion discrimination, emotion regulation, and cognitive control in childhood, adolescence, and adulthood. Frontiers in psychology, 2, 39 .

35. Urberg, K. A., Değirmencioğlu, S. M., \& Pilgrim, C. (1997). Close friend and group influence on adolescent cigarette smoking and alcohol use. Developmental psychology, 33(5), 834.

36. Wei-Cheng, M., \& Bikos, L. H. (2000). Educational and vocational aspirations of minority and female students: A longitudinal study. Journal of Counseling and Development: JCD, 78(2), 186.

37. Wentzel, K. R., \& Caldwell, K. (1997). Friendships, peer acceptance, and group membership: Realtions to academic achievement in middle school. Child development, 68(6), 1198-1209.

38. Youniss, J. (1983). Social construction of adolescence by adolescents and parents. New Directions for Child and Adolescent Development, 1983(22), 93-109. 